\title{
First report of fibroma in huemul (Hippocamelus bisulcus Molina 1782)
}

\section{Primer reporte de fibroma en huemul (Hippocamelus bisulcus Molina 1782)}

\author{
Ana Hinojosa ${ }^{1}$, Evan Blumer², Amy Camacho $^{3}$, Alejandra Silva ${ }^{4}$, Manuel Quezada ${ }^{5}$ \& Cristina \\ BREVIS ${ }^{5}$ \\ ${ }^{1}$ Departamento de Patrimonio Silvestre, Corporación Nacional Forestal. Address: Claudio Arrau n 738 Chillán, Región del \\ Biobío, Chile.e-mail: ana.hinojosa@conaf.cl \\ ${ }^{2}$ OsoMono Ltda. 1000 Creekside Plaza, 3rd Floor Gahanna, Ohio 43230 USA \\ ${ }^{3}$ African Safari. Address: Km 16, 5 Blvd. Cap. Carlos Camacho. Puebla, México. \\ ${ }^{4}$ Departamento de Patrimonio Silvestre, Corporación Nacional Forestal. Address: Av. Bulnes n 0209, Punta Arenas, Región \\ de Magallanes y la Antártica Chilena, Chile. \\ ${ }^{5}$ Departamento de Patología y Medicina Preventiva, Facultad de Ciencias Veterinarias, Universidad de Concepción, Chillán, \\ Región del Biobío, Chile. Address: Vicente Méndez nº 595 Chillán, Chile.
}

\begin{abstract}
An adult female huemul (Hippocamelus bisculcus), captured in Bernardo O'Higgins National Park, Chile, had melanic lesions on a large part of her body. After a histological analysis, these lesions were diagnosed as Fibroma. This is a common pathology for several deers of the world. However, we report the first medical study for the huemul deer.

KeYwords: Tumeur, deer, Bernardo O’Higgins National Park.

\section{RESUMEN}

Un ejemplar huemul adulto hembra (Hippocamelus bisculcus) fue capturado en el Parque Nacional Bernardo O'Higgins, el cual tenía gran parte de su cuerpo cubierto con lesiones melánicas. Después de un análisis histológico de estas lesiones, fueron diagnosticadas como Fibroma, una patología descrita como común en ciervos del mundo, sin embargo, en el huemul, este artículo constituye el primer reporte.
\end{abstract}

Palabras claves: Tumor, ciervo, Parque Nacional Bernardo O’Higgins.

\section{INTRODUCTION}

The southern huemul, Hippocamelus bisulcus Molina 1782, in Chile has been declared as a Natural Monument by the Ministry of Agriculture and "in danger of extinction" by the Ministry of the Secretary General of the Presidency and the law 19.300 .

Currently, the Regions of Aysén and Magallanes have the greatest number of these animals, constituting the primary refuge for the species. Of special interest, in this context, is the Bernardo O'Higgins National Park, which includes a surface area of 3,525,901 hectares, $26 \%$ of which is found in Aysén and the remaining 74\% in the Regions of Magallanes and Antártica Chilena.

The park's weather is influenced by Chile's Southern Ice Field, with lower temperatures and higher precipitation than continental areas. In Puerto Edén, a town near the park, the median annual temperature registered is $7.5^{\circ} \mathrm{C}$ and precipitation about $4000 \mathrm{~mm}$ per year.

There are three population nuclei of huemuls that are most studied in this park: Huemul Valley, Katraska Valley and Bernardo Valley. Studies have been carried out since 1999 using population surveys, distribution studies, and studies of habitat and feeding.

In 2010, a female huemul with melanic lesions on a large part of the body was captured and samples of the lesion were taken for diagnostic and laboratory analysis.

\section{METHODOLOGY}

The huemul was capture in the Katraska Valley (48 43'52"S$\left.73^{\circ} 59^{\prime} 86^{\prime \prime} \mathrm{W}\right)$ with authorization of the Agriculture and Livestock Service (Servicio Agrícola y Ganadero - SAG). 
The huemul was anesthetized through a combination of Medetomidine (Zoopharm ${ }^{\circledR}$ ) and Ketamine (Richmond ${ }^{\circledR}$ ), utilizing Pneudart ${ }^{\circledR}$ darts. Once the procedure was finished, Atipamezole (Pfizer ${ }^{\circledR}$ ) was utilized intramuscularly as a reverser of the Medetomidine. The huemul was observed until her recovery.

A surgical biopsy was performed on the external lesions, disinfecting the general area and extracting samples from two different sites. The samples were fixed and conserved in formaline at $10 \%$ and sent for analysis to the Pathology Laboratory of the Faculty of Veterinary Sciences, University of Concepción, Chillán Campus.

\section{RESULTS AND DISCUSSION}

The female had multiple pedunculated melanic tumoral structures of variable size. The lesions were concentrated on the face and neck (Fig. 1), but were also encountered on the flanks and extremities.

The histopathological diagnosis of the lesions showed the epidermis to be of variable thickness and with melanocytes in the basal stratum, and the dermis with proliferation of fusiform cells with oval nuclei, slightly eosinophilic cytoplasm, and with more abundant extra-cellular matrix than normal. The fibrocytes presented lineal growth. As well, the existence of melanocytes disseminated in the dermis and inflammatory infiltrate of polymorphonuclears were observed (Fig. 2). The symptoms agree with the diagnosis of Fibroma.

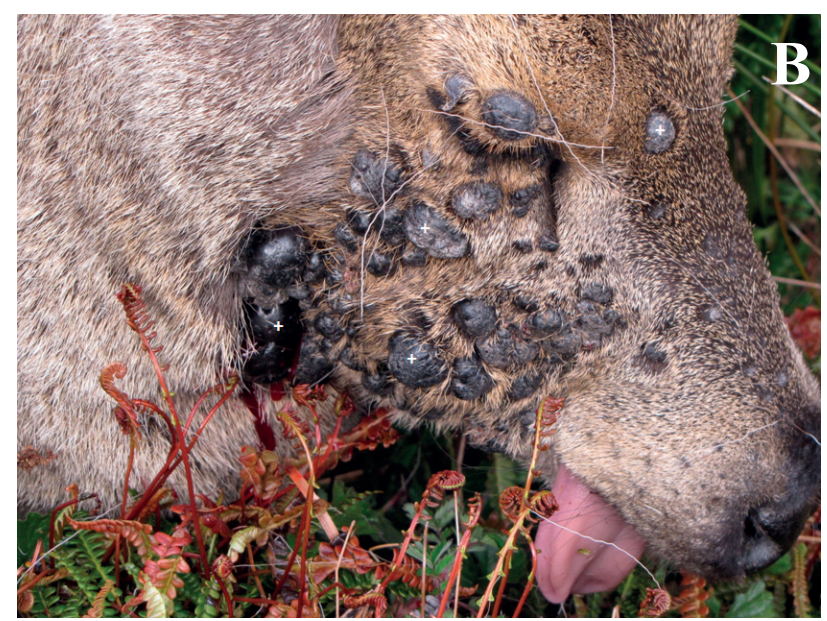

FIgURE 1. A, B. Female huemul with multiple melanic tumors (+) on the face and neck (Bernardo O'Higgins National Park, 2010).

Figura 1. A, B Hembra de huemul con múltiples tumores melánicos (+) en rostro y cuello (Parque Nacional Bernardo O Higgins, 2010).

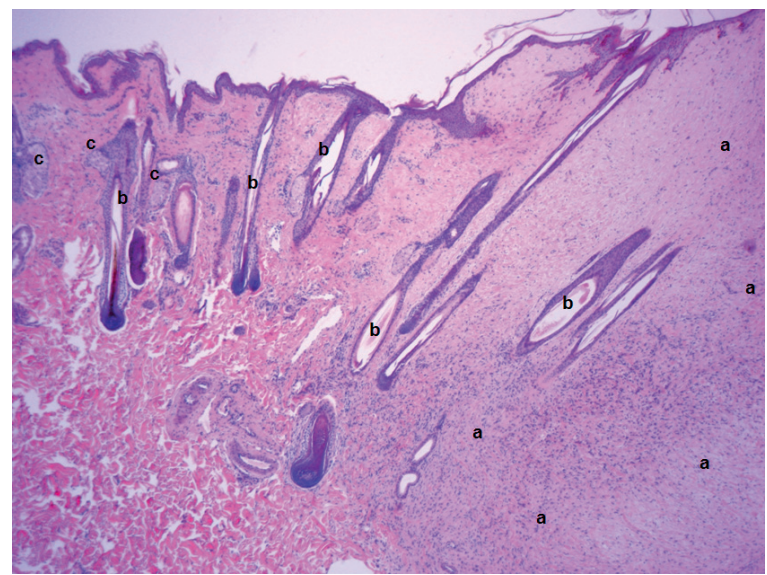

FiguRE 2. Microphotograph that shows normal tissue (to the left and down) and proliferation de fibrocytes (a) and diminution of hair follicles (b) and glands (c) (to the right and left up). H\&E, 400x.

Figura 2: Microfotografía que muestra tejido normal (izquierda, abajo) y proliferación de fibrocitos (a) y disminución de folículos pilosos (b) y glándulas (c) (derecha e izquierda arriba). H\&E, 400X. 
According to Sunbeg \& Nielsen (1981), fibromas are cutaneous neoplasms most often reported in deer, being described in white-tailed deer (Odocoileus virginianus), mule deer (Odocoileus hemionus), black-tailed deer (Odocoileus hemionus), red deer (Cervus elaphus), roe deer (Capreolus capreolus), sika deer (Cervus nipon), elk (Alces alces) and caribou (Rangifer caribu). The authors note a prevalence of this pathology between $1 \%$ and $5.4 \%$, with the majority of cases in animals younger than two years. This is consistent with the present finding given that the specimen had four permanent teeth and four deciduous teeth. The complete change of deciduous teeth in the huemul occurs at 30 months of age (Díaz \& Smith-Flueck 2000).

It is believed that the etiology of this set of symptoms is related to a virus and although the natural mode of transmission is unknown, hematophagous insects are suspected. Fibromas that continue to grow may result in visual obstruction if near the eyes or interfere with prehension when present around the mouth, but most tumors regress some months after development (Sunbeg \& Nielsen 1981). The development of the symptoms is unknown in the present study because the area where the huemul was captured is only visited by park personnel once per year. In 2005, similar lesions in huemul deer were reported from the Huilo Huilo Breeding Center, from two adult animals translocated from Aysén region. They were not histologically analyzed and regressed severals months later (Vidal 2010).

\section{ACKNOWLEDGMENTS}

We to thank the enormous support given by Don Jorge Pérez administrator of the National Park and the Park Rangers Aliro Vargas, Víctor Muñoz, Fredy Paredes, Guillermo Igor and Héctor Galaz.

\section{BIBLIOGRAPHY}

Díaz, N. \& Smith-Flueck, J. 2000. El Huemul Patagónico, un misterioso cérvido al borde de la extinción. L.O.L.A., Monografía $\mathrm{N}^{\circ}$ 3, Buenos Aires, Argentina. 170 págs.

SunBeg, J. \& Nielsen S. 1981. Deer Fibroma: A Review. Canadian Veterinary Journal 22: 385-388.

VIDAL, F. 2010. El Huemul un futuro posible. Fundación HuiloHuilo. Ed. Servicio Agrícola y Ganadero: Santiago, Chile. 89 págs. 